\title{
Upgrading Waste Management and Sustainability Reporting in Banking Industry - Evidence from Serbia ${ }^{4}$
}

\author{
Article history: \\ Received: 8 May 2018 \\ Sent for revision: 10 May 2018 \\ Received in revised form: 26 July 2018 \\ Accepted: 26 July 2018 \\ Available online: 2 October 2018
}

\begin{abstract}
This paper examines banking industry practice in the area of circular economy reporting with the specific emphasis on waste management reporting in this sector. Paper answers the basic question - is financial service sector exempt from the circular economy reporting requirements having low material usage and resource consumption? Manuscript indicates that in Serbia waste management reporting in banks is in the early stage. Most of the waste management indicators in banks are included as integral part of sustainability reports or as part of management report. Paper indicates that less than half of the bank population in Serbia prepares standard report required by the Environmental Protection Agency. Having in mind these results, banks managers and state officials should take into consideration the fact that most of the banks do not report on flow of waste and most of these indicators are not regularly published on website implying that stakeholders and investors are not adequately informed on the inclusion of banks into circular economy environment. Lagging behind waste management requirements could be potentially hazardous having in mind the fact that Serbia strives towards European Union membership where the legislation and practical alignment with the EU regulation is inevitable process.
\end{abstract}

Keywords: Circular economy, non-financial statements, management report, waste management report, banking industry

\footnotetext{
${ }^{1}$ Singidunum University, Faculty of Business, Belgrade, Serbia; gknezevic@singidunum.ac.rs

${ }^{2}$ University of Pristina, Faculty of Economics, K. Mitrovica, Serbia

${ }^{3}$ University of Belgrade, Faculty of Agricultural, Belgrade - Zemun, Serbia

4 This paper is a part of the results within research on project 179001 , financed by Ministry of education, science and technological development of the Republic of Serbia
} 
Knežević G., et al: Upgrading Waste Management and Sustainability Reporting in...

\title{
Nadogradnja izveštavanja o upravljanju otpadom i održivom razvoju u bankarskom sektoru - primer Srbije
}

\begin{abstract}
Apstrakt: U ovom radu istraživali smo praksu primene cirkularne ekonomije $u$ bankarskom sektoru sa posebnim osvrtom na izveštavanje o upravljanju otpadom. Rad je pokušao da odgovori na klasično pitanje - da li je sektor finansijskih usluga kojem pripadaju i banke, izuzet od izveštavanja u kontekstu cirkularne ekonomije iz razloga što imaju nisko učešće trošenja materijala $i$ prirodnih resursa prilikom obavljanja delatnosti? U ovom istraživanju indikativno je da u Srbiji izveštaj o upravljanju otpadom koji popunjavaju banke je u svom začetnom obliku. Najveći broj indikatora o upravljanju otpadom nalazi se u izveštaju o održivom razvoju koji banke pripremaju ili u izveštaju o poslovanju koji menadžment sastavlja radi polaganja računa stejkholderima. Istraživanje jasno ukazuje da ispod polovine banaka u Srbiji priprema standardni izveštaj koji zahteva Agencija za zaštitu životne sredine. Imajući $u$ vidu ove rezultate, regulatori $u$ državi, kao i menadžment banaka treba da imaju u vidu da banke ne prikazuju tokove otpada u svojim izveštajima, niti indikatore publikuju na svojim web stranicama. Ovo implicira da stejkholderi i investitori, kao važni korisnici, nisu adekvatno informisani o inkluziji banaka u sistem cirkularne ekonomije. Ukoliko i dalje budemo ostavljali po strani pitanja upravljanja otpadom, to može biti dodatni hazard imajući u vidu želju Srbije da bude punopravna članica EU gde je usklađivanje sa izuzetno obimnom regulativom u domenu upravljanja otpadom neizbežno.
\end{abstract}

Ključne reči: cirkularna ekonomija, nefinansijsko izveštavanje, izveštaj menadžmenta, izveštaj o upravljanju otpadom, bankarski sektor.

\section{Introduction}

Despite that the circular economy concept was defined at the beginning of the last decade of the 20th Century by Pearce and Turner (1990), in the last few years, circular economy is receiving increasing attention worldwide as a way to overcome the current production and consumption model based on continuous growth and increasing resource throughput (Ghisellini, et al, 2016, p.1). Circular economy is a topic highly discussed at the political level, but also within academic and non-governmental fora (Ionașcu \& Ionașcu, 2018, p. 356). Circular economy is a concept that currently receives a particular attention due to its contribution to the European objectives related to economic development under restrictive environmental conditions. In other words, the implementation of circular economy activities is essential to maintain and increase the competitiveness of the European economy (Ghenţa \& Matei, 2018, p. 294). 
Knežević G., et al: Upgrading Waste Management and Sustainability Reporting in...

The concept of circular economy is often confused with the recycling process; nothing more wrong because this limiting vision may be the least sustainable solution compared to other circular economy principles of reduction and reuse in terms of resource efficiency and profitability in real terms (Strat, et al, 2018, p. 280).

The circular economy is an emerging topic attracting increasing research interest (Sauvé et al, 2016, p.50). As Urbineti, Chiaroni and Chiesa (2017, 487) cited, "the circular economy has undoubtedly become one of the hot topics in public debates about new and more sustainable industrial paradigms and strategies". The most part of these researches came from the Chinese authors (Qi, et al, 2016; Wang, et al, 2014; Leng Chu, et al, 2012; Geng, et al, 2013; Wu, et al, 2014), but researches have been conducted in other countries as well, such as Japan (Takiguchi \& Takemoto 2008), the Netherlands (Fischer \& Pascucci, 2017), Italia, Poland (Ghisellini, et al, 2014), Norway (Lausselet, et al, 2017). Some studies are even more comprehensive like studies covering the EU area (Haas, et al, 2015) or developing countries (de Jong et al, 2016). Different perspectives are present between scholars, some are more focused on the macroeconomic and social conditions accompanying a higher circularity in the economy, while others are focused on businesses' and individuals' behaviours (Tăchiciu, 2018, p. 245).

Many researches on this topic are interdisciplinarity, multidisciplinarity and pluridisciplinarity (Sauvé et al, 2016, p.50). There are other scientific disciplines that do find themselves under the 'umbrella' of circular economy, such as chemical science (Clark et al, 2016), eco-tourism (Zhang; 2014), petrochemical industry (Qi et al, 2016), textile industry (Fischer \& Pascucci, 2017), agricultural and dairy production (Ghisellini, et al, 2014), bioeconomy (Cavallo, et al, 2015), electronics industry (O'Connor et al, 2016), biology (Liguori \& Faraco 2016), medicine (Koukoulias, et al, 2017), sociology and local economy (Haas, et al, 2016; Stahel, 2016; Andrews, 2015), business models and strategies (Witjes \& Lozano, 2016; Bocken et al, 2016; Lewandowski, 2016). The list of scientific disciplines included in the circular economy paradigm does not end here.

Some papers investigate if the transition from the linear economic model to the circular economic model has positive effects. Vuță, et al. (2018, p. 248) find that circular economy indicators, such as the recycling rate of municipal waste, packaging waste and bio-waste, the expenditure on research and development to find solutions to extend the life cycle of materials and reusing waste, as well as the environmental taxes have this effect on the resource productivity and real economic growth.

"The occurrence of the 'circular economy' concept is triggered by the degradation of the relationship between the economic system and the natural environment regarded as a system" (Negrei \& Istudor, 2018, p. 499). Today, 
Knežević G., et al: Upgrading Waste Management and Sustainability Reporting in...

the circular economy is considered as a necessary and pragmatic solution for reconciling the link between the growth rate and the pressure on the resources of the environment (Căutișanu,et al, 2018, p. 262). It is undoubted that "the circular economy concept is related to the sustainable development" (Vuță et al, 2018, p. 250). As Barbu et al. (2018, p. 374) state, "the circular economy is a desideratum of a sustainable economy".

The chosen business model in the circular economy is presumed to support sustainable development (Ionașcu, \& Ionașcu, 2018, p. 356). The circular economy should ensure the sustainability of economic processes (Pamfilie, et al, 2018, p. 388).

Despite the unbreakable bond between circular economy, waste management and sustainability, circular economy and reporting issues are rarely studied (Pratt, et al, 2016; Leng Chu, et al, 2012) as well as the accounting information disclosure issues (Wang, et al, 2014). On the other hand, sustainability reporting was researched by academicians in Serbia (see: Knežević, at al, 2017; Stojanović-Blab, et al., 2016), but information about waste management can rarely be found in these reports, regardless the fact that sustainability report, i.e. management report should contain information about waste management (see: Muminović \& Pavlović, 2011). Requirements for disclosure regarding environmental protection within Management report or Non-financial statement represents the EU Directive 2014/95 requirement as well (See: Milačić, et al, 2016; Pavlović \& Knežević, 2016). Those requirements are even more important having in mind the fact that Serbia has the EU candidate status.

An important aspect in supporting circular economy is related to waste management (Căutișanu,et al, 2018, p. 263). In 2015 European Commission passed the Circular Economy (CE) Package. The Package includes 4 legislations regarding waste management for the purpose of enforcing member states to move toward EU sustainability goals such as those published in the 'Next steps for a sustainable European future' (EC, 2016). This EC Communication views circular economy as 'transformative agenda with significant new jobs and growth potential and stimulating sustainable consumption and production patterns.' Together with these efforts a new platform regarding the financing problems of circular economy has been launched. In this specific case financial service sector and banks are viewed as providers of finance for the circular economy projects. But the purpose of this manuscript is to take a different angle on banks' role in the circular economy. By looking at banks as circular economy reporters not capital providers and financiers, situation is quite disappointing. It is obvious that banks lag far behind CE requirements. The reasons for this situation lie in the definition of $\mathrm{CE}$ and strong emphasis on sectors with high consummation of material in production. So, the next paragraph explains the origin of $\mathrm{CE}$ as 
Knežević G., et al: Upgrading Waste Management and Sustainability Reporting in...

well as its principles and why banking service sector does not find itself as a subject to CE requirements.

European Commission changes 4 regulations directly related to waste management in order to move closer to circular economy idea (EPRS, 2016): a) amending Directive 2008/98/EC on waste, b) amending Directive 1999/31/EC on the landfill of waste, c) amending Directive 94/62/EC on packaging and packaging waste, d) amending Directives 2000/53/EC on endof-life vehicles, 2006/66/EC on batteries and accumulators and waste batteries and accumulators, and 2012/19/EU on waste electrical and electronic equipment. Circular economy implies 'reducing waste to a minimum' and amending directives were issued in EU to stimulate movement of Member States toward zero waste. The EU circular economy package sets rigid targets regarding waste (EPRS, 2016, p. 7): municipal waste should be reused and recycled up to $65 \%$ in 2030 , municipal waste landfilled up to $10 \%$ in member states until 2030 and all packaging waste should be reused and recycled up to $75 \%$ in the year of 2030 . These optimistic targets require huge effort invested by all Member States in reaching them. CE package puts as well heavy reporting obligation on Member States requiring additional statistics regarding waste treatment to be collected as well as Member States progress toward EU waste targets to be reported. EU expects many benefits coming from the implementation of the CE package: 170,000 jobs created in the EU by 2035, greenhouse gas emissions will be avoided, the competitiveness of EU waste management, recycling and manufacturing sectors would be increased compared with the rest of the world and the dependency on material imports will be reduced. CE package will also improve environment and citizen's health across EU.

Although Serbia is not EU member state, waste management is considered to be necessary goal for this country as well. Serbia issued National Waste Management Strategy for the period 2010-2019 (Official Gazette, No. 29/2010) with the following objectives: waste management in Serbia should be harmonized with the EU policy in this area (legislation strengthening), responsibility for waste should be identified, Strategy sets waste management targets for short and long term period and establishes action plan to achieve those targets. The status of waste management treatment in Serbia was not satisfactory at all. The following statistics supports this opinion: municipal waste covers only $60 \%$ of population while rural areas are not covered by waste collection; there is no separate collection and sorting of waste in municipalities; most of the municipal waste is landfilled in official and wild dump sites; data on hazardous and non-hazardous waste is not precise, although the information and data base is collected by the Serbian Environmental Protection Agency. The Strategy sets the following long term objectives (Official Gazette, No. 29/2010): construction of 12 regional centres for waste management, provide capabilities for burning of organic industrial 
Knežević G., et al: Upgrading Waste Management and Sustainability Reporting in...

and medical waste, strengthening capacities for hazardous waste management and achieve the level of reuse and recycling of packaging material waste of $25 \%$ of its volume. The Unit for Environment Statistics within the Department for Business Statistics is responsible for waste statistics. Data on waste statistics is required from all companies with more than 10 employees. Since 2012, data about waste has been reported to EUROSTAT. The data about waste management in Serbia is collected in accordance with the Law on Waste Management (Official Gazette of the RS, No. 36/2009, $88 / 2010$ and 14/2016). Reporting includes all types of waste generated. Reporting units are: waste generator or the waste owner, waste operator, waste importer, dump site operator and all entities included in the movement of waste. All of them have an obligation to daily and annually report on all activities conducted regarding waste treatment and movement. The obligation to electronically send those reports to Serbian Environmental Protection Agency is also set. The information database has been in use since 2013 and about 15 different reports are electronically sent. One of them is named GIO 1 (Serbian annual waste management report prepared by waste producer). GIO 1 report includes types, quantity, source of waste, waste classification, transportation, depositing of waste, import and export of waste and the waste treatment - other companies are hired for this job, waste is stored on dumpsites and exported to be treated by other companies.

Obviously, banks are not directly mentioned as waste generators in this strategy. Banking sector is considered to be sector of low environmental influence when it comes to waste generation and disposition. On the other hand, this fact does not prevent banks to be included into the waste management reporting and to be required to send those reports to the specific governmental agency, as well as to report those activities to various bank's stakeholders.

In Serbian case, situation regarding circular economy and waste management reporting is in the early stage in all sectors, and banking industry is not an exception. Given the above mentioned, we assume that there will be many beneficiaries of our research results. This topic has rarely been researched by academicians in Serbia, therefore this research paper is addressed to various audiences. Research results could be used by policyholders in Serbia to encourage all banks to send annual waste reports to Serbian Environmental Protection Agency. On the other hand, research is beneficial to banks monitoring body such as the National Bank of Serbia (NBS). The National Bank is responsible for monitoring financial and non-financial reports prepared by banks. If low value of reporting is evidenced additional guidance by the NBS is needed. The results of research could be used to enhance the efficiency of waste report preparation by banks. This is especially true having in mind that two different waste reports are prepared (for the governmental agency and for stakeholders). 
Knežević G., et al: Upgrading Waste Management and Sustainability Reporting in...

This paper is structured as follows. Firstly, bank sector waste management requirements are presented followed with the review of scientific literature regarding circular economy, banks and sustainability. Secondly, the idea of inclusion of banks into CE is supported by available information and using content method authors try to understand the effectiveness of waste management in Serbian banks. Last part presents discussion of results and research limitations.

\section{Overview of banks' waste management reporting requirements}

Banks are the dominant institutions in the Serbian financial system (see more: Miljković et al, 2013; Ljumović et al, 2014; Ljumović \& Knežević, 2015; Pavlović \& Muminović, 2010). Banking sector in Serbia consists of 30 banks, 8 of them are in domestic ownership (state and private), while 22 is in foreign ownership (NBS; 2017). Sector results at the end of $1^{\text {st }}$ quarter 2017 are quite good because 24 banks operated with profit and 6 reported net loss. Profit distribution is concentrated. Seven banks contributed $75 \%$ to the sector profit. Banks are liquid and well capitalized (NBS, 2016): average monthly liquidity was 2.20 rising from 2.05 in the first quarter 2016 and it is above the regulatory minimum of 1.0 ; the capital adequacy was $22.34 \%$ which is well above the domestic regulatory capital minimum of $12 \%$.

Service business and banking industry, as its part, are not considered as a business that generates and uses hazardous materials and resources. On the other hand, we cannot arrive to the conclusion that this sector needs to be exempt from the circular economy. Ellen MacArthur Foundation report in 2013 points out that development of circular economy 'ultimately depends on the private sector ability to adapt and profitably develop the new business model' (Ellen MacArthur Foundation, 2013, p. 02). So, the development of circular economy is directly influenced by all sectors of economy. However, the above mentioned report focuses on the best practice for the sectors that holds the best potential for circularity (manufacturing sector). Banking industry does have that potential as well. This is also true when we take into consideration that banks already prepare sustainability reports using Global Reporting Initiative (GRI) guidelines known as G4 Sector Disclosure - Financial services. These are specific principles developed for the financial service sector. The financial service sector in those guidelines is subdivided into four categories: retail banking, commercial and corporate banking, asset management and insurance (GRI; 2013). GRI specific guidelines are developed as general framework for reporting on economic, environmental and social performance of a bank. Guidelines are specific in the area of bank's impact on environment. Environmental indicators in GRI specific 
Knežević G., et al: Upgrading Waste Management and Sustainability Reporting in...

guidelines cover performance related to inputs (e.g., material, energy, water) and outputs (e.g., emissions, effluents, waste). Many indicators are used in practice of sustainability reporting by banks such as direct energy consumption (natural gas or heating) or intermediate energy consumption (electricity for lighting). This energy can be used from traditional nonrenewable sources or renewable sources. Banks should also report on greenhouse gas emissions and ozone depleting substances used in their operations such as travelling.

According to GRI guidelines, banks should report on total weight of waste by type and disposal method. The primary type of waste in banks and financial service companies comes from IT products and paper used in their operations. Banks should report how much of waste is disposed or recycled, because the treatment of waste has different environmental impact. Most waste minimization strategies require from banks and other companies to provide options for minimizing disposing waste on dump sites. Those requirements focus on reusing or recycling options for waste treatment. GRI guidelines for banks make them accountable for waste treatment and direct them to prepare waste report.

By and large, despite the fact that banks are not directly included in the development of circular economy they have big potential for circularity. Potential of Serbian banks will be further explored in this article.

\section{Review of the scientific literature and development of hypothesis}

Concept of circular economy has its origins in Europe but is widely adopted and used as a research topic by many authors from China (Geissdoerfer, et al, 2017). Chinese authors presented four times more manuscripts regarding circular economy than authors from England, which is ranked as second. The most cited journal about this topic is Journal of Cleaner Production. But none of these publications and manuscripts refer to the application of circular economy paradigm of the service industry. This is due to the fact that even in the contemporary definitions of the term circular economy there are no ideas how financial service industry can be involved in this process. Many articles tackle other problems of sustainable development, such as paying taxes (Liu, et al, 2018).

Circular economy is a 'regenerative system in which resources input and waste, emission and energy leakage are minimized by slowing, closing and narrowing material and energy loops. This can be achieved through longlasting design, maintenance, repair, reuse, remanufacturing, refurbishing and recycling' (Geissdoerfer, et al, 2017, p. 759). The other definitions find that 
Knežević G., et al: Upgrading Waste Management and Sustainability Reporting in...

circular economy is an 'industrial system that is restorative or regenerative by intention and design ... it replaces the 'end-of-life' concept with restoration, shifts towards the use of renewable energy, eliminates the use of toxic chemicals, which impairs reuse, and aims at the elimination of waste through the superior design of materials, products, systems, and, within this, business models (Ellen MacArthur Foundation, 2013, p. 07).

From the above mentioned definitions it is clear that the terms maintenance, remanufacturing, refurbishing, toxic chemicals, product are directly correlated with the manufacturing company and tangible finished goods as final results of manufacturing. Usage of material inputs, changes in design and recycling effort contribute to the efficiency of the process and minimize environmental impact. Although it is not directly mentioned, financial service industry is also affected with circular economy movement.

Financial service industry and banks as its primary building block use energy (IT devices) and material (paper). Therefore, this industry can also contribute to closing the loop of environmental hazard by using renewable energy and elimination of waste in the service business. Some authors believe that interorganisational cooperation is needed but they still focus on cooperation between manufacturers and do not include financial service industry into the circular economy cooperative processes (Ruggieri, et al, 2016). In the white paper published by The Circle Economy \& Dutch Group in 2012, the role of service industry in circular economy was mentioned. This paper focuses on five sectors: financial sector, insurance companies, pension funds, employment agencies and head-hunters, and the IT sector (The Circle Economy \& Dutch Group, 2012). Taking the position that financial service sector has been a "mirror" of the real economy and that financial crisis shows how financial economy may have severe impact on real economy, underestimating the role that the financial service industry and banks play in the circular economy paradigm is not considered to be a wise strategy any more. Financial service industry affects circular economy in two different ways: firstly, financial services are finance providers for the circular economy, and secondly, financial service industry itself is changing because of it adopts new principles of circular economy. ING Economics department (2015) considers the ideas of achieving economic growth in sustainable manners. This bank develops the circular economy model to fit its business. In the paper named "Rethinking finance in the circular economy" ING bank provides an extremely good overview of solutions regarding financial circular business. According to (ING, 2015, p.8) circular economy affects banks in terms of changing the nature of cash flow and increasing capital needs of banks because of reshaping risk-return profile for those banks financing circular economy companies. It also influences legal issues in the context of using collateral and its value. If bank directs more assets and capital to sustainable business it can create a healthy portfolio and be seen as "credible and 
Knežević G., et al: Upgrading Waste Management and Sustainability Reporting in...

valuable strategic partner for entrepreneurs in circular economy" (ING, 2015, p.8).

The idea of embedding circular principles of "reduce, reuse and recycle" in the financial service sectors makes this sector more responsible toward environment. The future sustainability reports prepared by banks will be of a higher quality and this is in line with the fact that richer middle class, predicted to be a consequence of huge economic growth, has higher ecological footprint. This requires Serbian and other banks to be more environmentally and waste reduction sensitive than ever before. Developing environmentally and circular economy aware banks will also help in this regard.

In Serbia, circular economy movement is in the early stage. OEBS (2016) brochures state that Serbian circular economy starts with the introduction of new regulation which implies the adoption of the EC regulation and communication regarding circular economy. Having a candidate status, Serbia is required to adopt best European legislation. However, technological and developmental gap between Serbia and the rest of the world leading countries is wide. OEBS (2016) finds that if Serbia accepts circular economy it will bring many benefits in terms of reduction of transitional costs for moving from linear to circular economy. OEBS mission in Serbia, Conference of cities and municipalities, Ministry of Agriculture and Serbian Chamber of commerce organized a series of round tables in different cities in Serbia trying to increase their capacity and awareness towards circular economy. Deutsche Gesellschaft für Internationale Zusammenarbeit (GIZ) $\mathrm{GmbH}$ project in the context of waste management in municipalities will support the implementation of new circular philosophy in Serbia. That is why many papers in Serbian context are focused on waste. In Serbia, waste management and circular economy principles are not adequately applied and there is the obvious lack of economic incentive measures and significant waste disposal amount (llić \& Nikolić, 2016). Municipal solid waste management in Serbia is key obstacle for the achievement of sustainable development (Prokić \& Mihajlov, 2012). Quantity of generated waste is still growing in Serbia and very low percent of recyclables is separated from the waste stream, so integrated sustainable waste management is necessary (Popović, et al, 2016). There are other incentives such as introducing gender issue in the waste management (Baćanović, 2011). Based on the papers regarding circular economy which consider waste management, in this manuscript we pointed out waste management reports of Serbian banks and how those reports required by the Law fit into the sustainability and non-financial reporting.

Given the above, the following presented hypotheses could be tested:

$\mathrm{H} 1$ : Banks in Serbia do not prepare report on movement of waste on a regular basis. 
Knežević G., et al: Upgrading Waste Management and Sustainability Reporting in...

Although the Law on Waste Management consider banks as waste producers and therefore makes them responsible for preparing the waste reports we propose that not all of the banks prepare this required report. According to Article 26 of the Law on Waste Management (Official Gazette of the Republic of Serbia, No. 36/2009, 88/2010 and 14/2016), the waste producer has a responsibility to prepare plans of waste movement and treatment if producer produce more than $200 \mathrm{~kg}$ of dangerous waste and more than 100 tons of non-dangerous waste. Producer of waste has an obligation to prepare report on waste treatment including data for waste recycled, deposited or given to other companies for treatment. Document of the waste movement should be submitted by waste producer (Article 45 of the Law). Reporting on waste is defined in the article 75 , which directly requires waste producer to prepare daily and annual report on waste treatment. Obviously banks are accountable to prepare waste reports because they are waste producers according to the law. In the report, banks should report on type, quantity, source of the waste, characterization and classification of waste produced, structure of waste, waste deposited on the landfill or elsewhere, transport, export and import of waste and additional usage of some elements of waste or waste given to the licensed company. This report is called GIO 1 (annual report on waste treatment). It is prepared and submitted to the Serbian Environmental Protection Agency. The Agency collects reports and prepares analysis on waste treatment in Serbia. Reports have been collected since 2013.

H2: Banks preparing waste reports for the Environmental Protection Agency also present information about waste in management report as part of their external accountability to stakeholders or in other non-financial reports such as sustainability report.

Sustainability reports are voluntary for banks and sometimes banks include elements of this report into management report. Sustainability report is treated as non-financial report. Other reports prepared by banks in Serbia are financial reports by using IFRS (International Financial Reporting Standards) background. Those reports are not used in the research of waste treatment because we cannot find any information regarding waste. In this case we propose that banks preparing waste management report for the Serbian Environmental Protection Agency have better quality of sustainability reports or management reports in terms of having more information presented regarding waste management.

H3: Banks preparing waste management report are more prone to finance corporate sector circular economy projects than other banks not preparing such reports.

Banks preparing waste management report are considered to be circular economy aware banks so they should finance more 'green' projects. We will 
Knežević G., et al: Upgrading Waste Management and Sustainability Reporting in...

try to check whether this is true by observing the type of loans that banks offer on their official website.

In the next section of the paper we introduce methodology of the research and sample for testing the above mentioned hypotheses.

\section{Research methodology and sample description}

Methodology of the research is based on secondary data collected by the Agency or on the data provided by banks on their web sites and management report. Management report is prepared by all banks and its content covers the environmental protection where banks provide information regarding waste treatment. However, sustainability reports are voluntary and they are found on the banks' web site if a specific bank decides to prepare it. Given the above, the main methodology used in this research is content analysis (Neuman, 2014). Content analysis is used in social research as non-reactive research method in which participants, banks in this case, are not aware that information about them has been collected. 'Content analysis is a technique for examining the content or information and symbols contained in written documents or other communication media' (Neuman, 2014, p.49). After the collection, we systematically analyse the material using tables, graphs and charts.

Hypothesis in this research will be tested on the sample consisting of 30 commercial banks in Serbia for which we have data and for the National bank of Serbia as a supervisory bank which is also required to prepare waste management report. Total number of banks in Serbia in 2016 is 30 . Not all of the banks in the sample prepare GIO 1 report required by the Law. Number of observations with the data will be much lower than the number of banks in the sample.

Table 1 - Sample characteristics

\begin{tabular}{|l|c|c|c|c|}
\hline & $\mathbf{2 0 1 3}$ & $\mathbf{2 0 1 4}$ & $\mathbf{2 0 1 5}$ & $\mathbf{2 0 1 6}$ \\
\hline $\begin{array}{l}\text { Banking sector (total } \\
\text { number of banks) }\end{array}$ & 30 & 29 & 30 & 30 \\
\hline State-owned banks & 6 & 6 & 6 & 6 \\
\hline Domestic Private banks & 3 & 2 & 1 & 2 \\
\hline Foreign banks & 21 & 21 & 23 & 22 \\
\hline
\end{tabular}

Source: NBS, 2016 and 2013, p. 55 
Knežević G., et al: Upgrading Waste Management and Sustainability Reporting in...

Sample description is given below (see Table 1). Total number of banks in the sample in the period covered by the research ranges from 29 to 30 . There are always 6 state-owned banks in the sample and 3 to 1 domestic private bank. The rest of the sample consists of foreign banks. The number of foreign banks ranges from 21 to 23 . Credit portfolio at the end of 2016 was 1,784 billion Serbian dinars and it was distributed approximately $49 \%$ to corporate sector and the rest was given to individuals and households (NBS, 2016, p. 47).

Banking sector in the period of our observations is relatively stable for the banking sector. So, our research results are not jeopardized with the external distracting events.

Table 2 - No. of banks delivering Waste Management report to the Environmental Protection Agency in the period 2013-2016

\begin{tabular}{|l|c|c|c|c|}
\hline \multicolumn{1}{|c|}{ Banks } & $\mathbf{2 0 1 3}$ & $\mathbf{2 0 1 4}$ & $\mathbf{2 0 1 5}$ & $\mathbf{2 0 1 6}$ \\
\hline $\begin{array}{l}\text { No. of commercial banks } \\
\text { delivering the waste report }\end{array}$ & 8 & 8 & 13 & 14 \\
\hline \% of the total banks & $31 \%$ & $27.5 \%$ & $43.3 \%$ & $46.6 \%$ \\
\hline National Bank of Serbia & 1 & 1 & 1 & 1 \\
\hline
\end{tabular}

Source: Ministry of Environmental protection/Environmental Protection Agency, PRTR section from the http://www.sepa.gov.rs/DostavljanjePodataka/Default.aspx (approached on October 2017)

From Table 2 we can conclude that from 2013 to 2016, the number of banks delivering management reports ranges from $31 \%$ in 2013 , up to $46.6 \%$ in 2016. The lowest level of waste management report presentation was in 2014 when $27.5 \%$ of all banks from the sample presented waste management report. Table 2 indicates that the National Bank of Serbia has an obligation to report on waste management.

Table 3-Commercial Banks delivering Waste management report to government and stakeholders

\begin{tabular}{|c|c|c|c|}
\hline Year & $\begin{array}{c}\text { Waste report for } \\
\text { the government }\end{array}$ & $\begin{array}{c}\text { Waste information or circular } \\
\text { economy information } \\
\text { delivered to stakeholders }\end{array}$ & $\begin{array}{c}\% \text { of banks } \\
\text { presenting } \\
\text { both reports }\end{array}$ \\
\hline 2013 & 8 & 3 & $37.5 \%$ \\
\hline 2014 & 8 & 3 & $37.5 \%$ \\
\hline 2015 & 13 & 3 & $23 \%$ \\
\hline 2016 & 14 & 3 & $21.4 \%$ \\
\hline
\end{tabular}

Source: Author's own calculations 
Knežević G., et al: Upgrading Waste Management and Sustainability Reporting in...

Table 3 shows that from all commercial banks with the waste report submitted to the governmental agency in 2013 , only 3 of them or $37.5 \%$ showed waste management section within the Management report as part of external accountability to stakeholders. The same is true for 2014. Number of banks presenting report to the governmental agency rose to 13 in 2015, while only $23 \%$ or two banks were still reporting to the stakeholders. In 2016, 3 out of 14 banks decided to prepare waste management section within the Management report as part of Annual report for stakeholders. Those three banks are owned by foreign bank holder.

Table 4 - The National Bank delivering Waste management report to government and stakeholders

\begin{tabular}{|l|c|c|}
\hline \multicolumn{1}{|c|}{ Year } & $\begin{array}{c}\text { Waste report for the } \\
\text { government }\end{array}$ & $\begin{array}{c}\text { Waste information/circular economy } \\
\text { information delivered to stakeholders }\end{array}$ \\
\hline 2013 & prepared & prepared \\
\hline 2014 & prepared & prepared \\
\hline 2015 & prepared & prepared \\
\hline 2016 & prepared & prepared \\
\hline
\end{tabular}

Source: Author's own data

National Bank of Serbia (NBS) in observed period shows waste management responsibility and it prepares reports for both purposes (see Table 4). The quality of the waste information prepared to stakeholders in NBS is much better than the quality of any waste information presented to stakeholders by commercial banks.

Table 5 - Content and quality of Waste management information provided to bank's stakeholders

\begin{tabular}{|l|l|l|}
\hline \multicolumn{1}{|c|}{ Banks } & $\begin{array}{c}\text { Where is the information } \\
\text { presented? }\end{array}$ & \multicolumn{1}{|c|}{ Quality } \\
\hline National Bank of Serbia & Social responsibility report & $\begin{array}{l}\text { Detailed, qualitative and } \\
\text { quantitative (1-2 pages) }\end{array}$ \\
\hline Eurobank & Within Management report & $\begin{array}{l}\text { One paragraph, qualitative } \\
\text { information }\end{array}$ \\
\hline Erste bank & Social responsibility report & $\begin{array}{l}\text { One paragraph, qualitative } \\
\text { information }\end{array}$ \\
\hline Piareus bank & $\begin{array}{l}\text { Green banking 4Life } \\
\text { project }\end{array}$ & $\begin{array}{l}\text { Detailed, qualitative and } \\
\text { quantitative }\end{array}$ \\
\hline
\end{tabular}

Source: Author's own calculations 
Knežević G., et al: Upgrading Waste Management and Sustainability Reporting in...

According to Table 5, detailed information regarding waste management and circular economy was presented by National bank of Serbia in report entitled as social responsibility report. One bank shows recycling efforts as part of its social report, while the other one shows waste management section within Management report. Piraeus shows external accountability towards circular economy within internal banking project. The best quality of waste reporting to stakeholders was delivered by the National Bank of Serbia.

Table 6 - Banks preparing waste report/information and green project finance

\begin{tabular}{|l|c|c|c|}
\hline & No. of bank & $\begin{array}{c}\text { Green projects } \\
\text { financed }\end{array}$ & $\%$ \\
\hline $\begin{array}{l}\text { Banks preparing waste } \\
\text { management report to } \\
\text { governmental agency }\end{array}$ & 14 & 5 & $35.7 \%$ \\
\hline $\begin{array}{l}\text { Banks preparing report to } \\
\text { government and stakeholders }\end{array}$ & 3 & 2 & $66.6 \%$ \\
\hline
\end{tabular}

Source: Author's own calculations

The results in Table 6 indicate that only 5 out of 14 banks or $35.7 \%$ finance circular economy projects or "green" projects. Only one bank uses external international credit lines authorised by European Investment bank for these projects, while 4 banks from the sample use and finance green projects as part of their own credit policy.

\section{Results and discussion}

Circular economy and waste management reporting in Serbian banking industry is not adequately applied. The research results show that number of banks preparing waste report (GIO1) to the governmental agency rose from 8 to 15 banks in the observed period meaning that banks find themselves more responsible towards waste management. We assume that number of banks reporting for this purpose will be even higher in the future because it is part of their legal obligation. Hypothesis $\mathrm{H} 1$ is proven to be true because banks in Serbia do not prepare waste management reports on a regular basis. Only $46.6 \%$ from the population report waste management information. National Bank of Serbia reports to the government and shareholders on a regular basis in the observed period.

The results are quite disappointing when reporting to stakeholders comes to the light. It seems than banks are not willing to present waste management information to their external users. In the observed period 3 commercial banks present this kind of information as well as the National Bank of Serbia. Quality of waste management information presented for stakeholders is low, only the 
Knežević G., et al: Upgrading Waste Management and Sustainability Reporting in...

National Bank presents all details regarding waste management including quantitative data as well, while other banks from the sample present qualitative information. From this we can conclude that banking industry in Serbia has not place circular economy and waste management at their external non-financial reporting agenda.

Other banks present environmental information but circular economy aspect or waste management aspect is not considered in the report. All of the above presented data do not confirm hypothesis $\mathrm{H} 2$. Serbian banks rarely present in their management or social reports data regarding waste and circular economy.

Hypothesis $\mathrm{H} 3$ is also rejected because only $35.7 \%$ of banks preparing governmental waste management report show credit lines opened for financing green projects. Banks in Serbia are not quite willing to finance green projects as part of their external credit activity. This is due to the fact that green projects are not on the Serbian entrepreneurship agenda. Low green project ideas are developed by banks in order not to open extensive credit lines for these purposes.

This research does not come without limitations. Firstly, it is sector specific and country specific. Banking sector produces low quantity of waste and it is not treated as an important sector of circular economy. Therefore, the results cannot be generalized for this sector. Serbia is a transition country with the EU candidate status, so banking industry and EU circular economy requirements are less specific and more general than in EU Member countries. Our results are influenced with transition process in banking industry. More banks are owned by foreign bank acquirer and that is why their level of sustainability and waste management reporting is influenced by the foreign bank policies and procedures.

\section{Conclusion}

Banks' waste reports are prepared for two users: government and stakeholders. Governmental agency to which reports are submitted is called the Environmental Protection Agency. All reports are submitted electronically and the Agency maintain database since 2013. Since 2013, less than half of the total population of banks have submitted the reports to the Agency. Although this number is increasing, the results are surprising taking into consideration the fact that waste reporting is mandatory. Quality of the sustainability or management report prepared to stakeholders was also evaluated. The National Bank of Serbia is the only one that includes all waste management qualitative and quantitative indicators in its social responsibility report, while three commercial banks report only qualitative indicators. The 
Knežević G., et al: Upgrading Waste Management and Sustainability Reporting in...

rest of the sample prepares no information regarding waste in its sustainability or other reports. This fact implies additional guidelines to be issued by the National Bank of Serbia in which all commercial banks will be required to report indicators regarding waste on standard basis. This activity of NBS would increase the quality and details of information presented to stakeholders. In order to foster the efficiency of reporting, NBS may issue regulation in which waste information prepared to the governmental agency can be used in social responsibility reports as well. This would decrease costs of preparing two types of waste reports and we think that more banks from the sample will be willing to report on waste if such guidelines are issued.

On the other hand, the results of our research show the lack of adequate governmental policies and regulations for the service sector. It seems that this sector does not feel responsible for the waste production and treatment, and consequently less than $50 \%$ of banks report on waste to the government. Changes in regulation are very important. New regulation should place an emphasis on service sector companies as circular economy participants, not only on their waste regulation about the manufacturing sector. Including banks into the circular economy, more green projects will be financed and this would help Serbian economy to achieve waste goals set in the National Strategy.

Future research in this area should concentrate on cross-country analysis of banking sector's involvement in the circular economy. We propose to future researchers to adapt their research and include more service sectors companies (insurance companies, IT sector) to avoid limitations of the results.

\section{References}

Andrews, D. (2015). The circular economy, design thinking and education for sustainability. Local Economy, 30(3), 305-315.

Baćanović, V. (2011). Rod i upravljanje otpadom, uvođenje rodne perspektive u lokalne planove upravljanja otpadom [trans: Gender and waste management, introducing gender perspective into local plans of management treatment], GIZ, Deutsche Gesellschaft fur Internationale Zusammenarbeit.

Barbu, C.M., Florea, D.L, Ogarcă, R.F., \& Barbu, M.C.R., 2018. From Ownership to Access: How the Sharing Economy is Changing the Consumer Behavior. Amfiteatru Economic, 20(48), 373-387.

Bocken, N. M., de Pauw, I., Bakker, C., \& van der Grinten, B. (2016). Product design and business model strategies for a circular economy. Journal of Industrial and Production Engineering, 33(5), 308-320.

Cavallo, M., \& Gerussi, E. (2015). Bioeconomy, circular economy and industrial symbiosis: towards a new concept of productive processes. Eco-Industrial Parks, 43. 
Knežević G., et al: Upgrading Waste Management and Sustainability Reporting in...

Căutișanu, C., Asandului, L, Borza, M., \& Turturean, C. (2018). Quantitative Approach to Circular Economy in the OECD Countries, Amfiteatru Economic, 20(48), 247277.

Clark, J. H., Farmer, T. J., Herrero-Davila, L., \& Sherwood, J. (2016). Circular economy design considerations for research and process development in the chemical sciences. Green Chemistry, 18(14), 3914-3934.

de Jong , S., van der Gaast, M., Kraak, J., Bergema, R., \& Usanov, A. (2016). The circular economy and developing countries: a data analysis of the impact of a circular economy on resource-dependent developing nations. The Hague Centre for Strategic Studies.

European Parliament and the Council (2014). Directive, 2014/95/EU Amending Directive 2013/34/EU as regards the disclosure of non-financial and diversity information by certain large undertakings and group.

European Committee (2016). Next step for a Sustainable European Future,

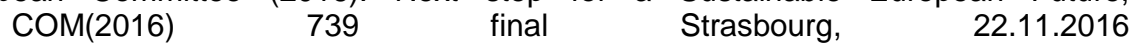
(https://ec.europa.eu/europeaid/sites/devco/files/communication-next-stepssustainable-europe-20161122 en.pdf (6 .10.2017)

Ellen MC Arthur Foundation, 2013. Towards the Circular Economy Economic and Business Rationale for an accelerated transition. https://www.ellenmacarthurfoundation.org (18 .09.2017)

EPRG (2016). Circular Ecomomy package. Four legislative proposals for waste. http://www.europarl.europa.eu/EPRS/EPRS-Briefing-573936-Circular-economypackage-FINAL.pdf (18.09.2017.)

Fischer, A., \& Pascuccl, S. (2017). Institutional incentives in circular economy transition: The case of material use in the Dutch textile industry. Journal of Cleaner Production, 155, 17-32.

Geissdoerfer, M., Savaget, P, Bocken, N., \& Hultink, E-J. (2017). The Circular Economy - A new sustainability Paradigm, Journal of Cleaner Production, No. $143,757-768$.

Ghența, M., \& Matei, A. (2018). SMEs and the Circular Economy: From Policy to Difficulties Encountered During Implementation. Amfiteatru Economic, 20(48), 294-309.

Ghisellini, P., Cialani, C., \& Ulgiati, S. (2016). A review on circular economy: the expected transition to a balanced interplay of environmental and economic systems. Journal of Cleaner Production, 114, 11-32.

Ghisellini, P., Protano, G., Viglia, S., Gaworski, M., Setti, M., \& Ulgiati, S. (2014). Integrated agricultural and dairy production within a circular economy framework. A comparison of Italian and Polish farming systems. Journal of Environmental Accounting and Management, 2(4), 367-384.

GRI (2013). G4-Sector Disclosures- Financial services. https://www.globalreporting.org/.../GRI-G4-Financial-Services (acces18.09.2017)

Haas, W., Krausmann, F., Wiedenhofer, D., \& Heinz, M. (2015). How circular is the global economy?: An assessment of material flows, waste production, and recycling in the European Union and the world in 2005. Journal of Industrial Ecology, 19(5), 765-777.

Haas, W., Krausmann, F., Wiedenhofer, D., \& Heinz, M. (2016). How Circular Is the Global Economy? A Sociometabolic Analysis (pp. 259-275). In: Haberl H., Fischer-Kowalski M., Krausmann F., Winiwarter V. (eds) Social Ecology. Human-Environment Interactions, vol 5. Springer, Cham.DOI: 
Knežević G., et al: Upgrading Waste Management and Sustainability Reporting in...

https://doi.org/10.1007/978-3-319-33326-711 (18.09.2017.)

Ilić, M., \& Nikolić, M. (2016). Drivers for development of Circular economy. A case study of Serbia, Habitat International, No. 56, 191-200

ING Economics department. 2015. Rethinking finance in circular economy, website: https://www.ing.nl/media/ING_EZB_Financing-the-Circular-Economy_tcm16284762.pdf (accessed 18 September 2017)

Ionașcu, I., \& Ionașcu, M. (2018). Business Models for Circular Economy and Sustainable Development: the Case of Lease Transactions. Amfiteatru Economic, 20(48), 356-372.

Koukoulias, K., Papadopoulou, A., Savopoulos, N.,Deligiannni, E., Orfanidou, T., Zervas, D., Xagorari, A., Yiango U, M., Anagnostopoulos A., Yannaki, E., \& Kaloyannidis, P. (2017). Non-transplantable cord blood units as a new source for adoptive immunotherapy of leukemia and a paradigm of circular economy in medicine. Cytotherapy, 19(5), S18.

Knežević, G., Pavlović, V., Stevanović, S. (2017). Izveštavanje o održivom razvoju karakteristike, ograničenja i perspekiva u Republici Srbiji [Reporting on sustainable development - characteristics, disadvantages and perspectives in the Republic of Serbia], Poslovna ekonomija, 10(1), 83-102.

Lausselet, C., Cherubini, F., Oreggioni, G. D., Del Alamo Serrano, G., Becidan, M., Hu, X., Rorstad, P., \& Stromman, A. H. (2017). Norwegian Waste-to-Energy: Climate change, circular economy and carbon capture and storage. Resources, Conservation and Recycling, 126, 50-61.

Leng Chu, C., Chatterjee, B., \& Brown, A. (2012). The current status of greenhouse gas reporting by Chinese companies: A test of legitimacy theory. Managerial Auditing Journal, 28(2), 114-139.

Liu, N., Liu, R., Huang, J., \& Chen, L. (2018). Pollution, Happiness and Willingness to Pay Taxes: The Value Effect of Public Environmental Policies. Problemy ekorozwoju, 13(1), 75-86.

Ljumović, I., Pavlović, V., \& Cvijanović, J. M. (2014). Two aspects of concentration in Serbian banking sector. Industrija, 42(3), 61-77

Ljumović, I., \& Knežević, G. (2015). Characteristics and perspectives of private banking: Overview of the Serbian market. Bankarstvo, 44(4), 88-107.

Milačić, Lj., Knežević, G., \& Pavlović, V. (2016). Problemi računovodstvenog izveštavanja o nefinansijskim informacijama o zaštiti životne sredine prema Direktivi 2014/95/EU [Accountancy problems of environmental non -financial information reporting according to the Directive 2014/95/EU], Ecologica, 23(84), $736-741$

Miljković, M., Filipović, S., \& Tanasković, S. (2013). Profitability of Serbian banking sector during global economic crisis. Industrija, 41(4), 39-57.

Muminović, S., \& Pavlović, V. (2011). Uticaj koncepta društveno odgovornog ponašanja na rentabilnost kompanija - studija slučaja grupacija Aquafil Italija [Impact of socially responsible behaviour concept on company profitability Case study Aquafil Group Italy]. Industrija, 39(1), 21-46.

National bank of Serbia (2016). Godišnji izveštaj o stabilnosti finansijskog sistema (Annual report on stability of financial system). http://www.nbs.rs/internet/latinica/90/fs.html (Accessed on 05 September 2017)

National bank of Serbia (2017). Banking sector in Serbia- first quarter report, Belgrade. https://www.nbs.rs/internet/english/55/55_4/quarter_report_I_17.pdf (accessed on 05 September 2017) 
Knežević G., et al: Upgrading Waste Management and Sustainability Reporting in...

Nannab, L., Rong L., Jian, H., \& Lingshuang, C. (2018). Pollution, Happiness and Willingness to Pay Taxes: The Value Effect of Public Environmental Policies, Problemy Ekorozwoju, vol. 13 (19, pp. 75-86)

Negrei, C., \& Istudor, N. (2018). Circular Economy - Between Theory and Practice, Amfiteatru Economic, 20(48), 498-509.

Numan,W.L. (2014). Social Research Methods:Qualitative and Quantitative Approaches, Pearson, Edinburgh Gate, Harlow.

Lewandowski, M. (2016). Designing the business models for circular economyTowards the conceptual framework. Sustainability, 8(1), 43. doi:10.3390/su8010043

Liguori, R., \& Faraco, V. (2016). Biological processes for advancing lignocellulosic waste biorefinery by advocating circular economy. Bioresource technology, 215, 13-20.

O'Connor, M. P., Zimmerman, J. B., Anastas, P. T., \& Plata, D. L. (2016). A strategy for material supply chain sustainability: enabling a circular economy in the electronics industry through green engineering. ACS Sustainable Chemistry \& Engineering, 4(11), 5879-5888.

OEBS (2016). Cirkularna ekonomija kao šansa za razvoj Srbije [trans: Circular economy: chance for Serbia's development], web site: http://www.osce.org/sr/serbia/292311(accessed on 9/18/2017)

Pamfilie, R., Firoiu, D., Croitoru, A.G., \& Ionescu, G.H.I. (2018). Circular Economy - A New Direction for the Sustainability of the Hotel Industry in Romania? Amfiteatru Economic, 20(48), 388-404.

Pavlović, V., \& Knežević, G., Izveštavanje o nefinansijskim informacijama za potrebe internih i eksternih korisnika [Non-financial reporting for the internal and external users], 20. međunarodni kongres "Finansijsko izvještavanje kao katalizator rasta ekonomije", Savez računovođa i revizora Republike Srpske, Banja Vrućica 15., 16. i 17. septembar 2016, 205- 226

Pavlović, V., \& Muminović, S. (2010). Značaj razvoja finansijskih tržišta za srpsku privredu [Significance development of financial markets for Serbian economy]. Industrija, 38(4), 41-67.

Pearce, D.W., \& Turner, R.K., 1990. Economics of Natural Resources and the Environment, Baltimore: The Johns Hopkins University Press.

Popović, F.J., Filipović, J.V., \& Božanić, V.N. (2013). Paradigm shift needed municipal solid waste management in Belgrade, Serbia, Hemijska industrija, 67(3), 547-557.

Pratt, K., Lenaghan, M., \& Mitchard, E. T. (2016). Material flows accounting for Scotland shows the merits of a circular economy and the folly of territorial carbon reporting. Carbon balance and management, Sep 8;11(1):21.

Prokić, D., \& Mihajlov, A. (2012).Contaminated sites. Practice of solid waste management in a developing country Serbia. Environment Protection Engeneering, Vol. 38 (1), 81-90.

QI, J., Zhao, J., Li, W., Peng, X., Wu, B., \& Wang, H. (2016). The Circular EconomyOriented Practice in the Petrochemical Industry. In Development of Circular Economy in China (pp. 169-182). Springer Singapore.

Republic of Serbia (2010). National Waste Management Strategy for the period 20102019 (Official Gazette, No. 29/2010) http://ecodev.rs/sr/documents/3\%20Nezvanicni\%20prevodi\%20dokumenata\%20 na\%20engleski\%20jezik/5\%20Otpad/Waste-management-strategy-for-the- 
Knežević G., et al: Upgrading Waste Management and Sustainability Reporting in...

period-2010-19.pdf (18.09.2017)

Ruggieri , A., Braccini, A. M., Poponi, S., \& Mosconi, E. M. (2016). A Meta-Model of Inter-Organisational Cooperation for the Transition to a Circular Economy, Sustainability, No. 8, doi:10.3390/su8111153 www (accessed on 18 September 2017)

Sauvé, S., Bernard, S., \& Sloan, P. (2016). Environmental sciences, sustainable development and circular economy: Alternative concepts for trans-disciplinary research. Environmental Development, 17, 48-56.

Stahel, W. R. (2016). Circular economy: a new relationship with our goods and materials would save resources and energy and create local jobs. Nature, 531(7595), 435-439.

Stojanović-Blab, M., Blab, D., \& Spasić, D. (2016). Sustainability reporting-a challenge for Serbian companies. Teme, 40(4), 1349-1366.

Strat, V.A, Teodor, C, \& Săseanu, A.S. (2018). The Characterization of the Romanian Circular Economy's Potential at County Level, Amfiteatru Economic, 20(48), 278-293.

Tăchiciu, L. (2018). The Circular Economy between Desiderates and Realities, Amfiteatru Economic, 20(48), 245-246.

Takiguchi, H., \& Takemoto, K. (2008). Japanese 3R policies based on material flow analysis. Journal of Industrial Ecology, 12(5-6), 792-798.

The circle economy \& Dutch Group (2012). Transforming professional service industry towards circular service, web site: https://mvonederland.nl/system/files/media/whitepapercircleservice.pdf (18.09.2017)

Urbinati, A., Chiaroni, D., \& Chiesa, V. (2017). Towards a new taxonomy of circular economy business models. Journal of Cleaner Production, 168, 487-498

Witjes, S., \& Lozano, R. (2016). Towards a more Circular Economy: Proposing a framework linking sustainable public procurement and sustainable business models. Resources, Conservation and Recycling, 112, 37-44.

Vuță, M., Vuţă, M., Enciu, A., \& Cioacă, S.L. (2018). Assessment of the Circular Economy's Impact in the EU Economic Growth, Amfiteatru Economic, 20(48), 248-261.

Wang, P., He, F., Fan, S., \& Gu, C. (2014). Ownership governance, institutional pressures and circular economy accounting information disclosure: An institutional theory and corporate governance theory perspective. Chinese Management Studies, 8(3), 487-501.

Wu, H. Q., Shi, Y., Xia, Q., \& Zhu, W. D. (2014). Effectiveness of the policy of circular economy in China: A DEA-based analysis for the period of 11 th five-year-plan. Resources, conservation and recycling, 83, 163-175.

Zhang, Y. (2014). Circular Economy Perspective Research Wanlu Lake Eco-tourism Industry Gathering Area for Innovation and Development. In Advanced Materials Research (Vol. 962, pp. 2301-2309). Trans Tech Publications. 